Dr Branislav Fatić

eks-savetnik Saveznog ministra pravde, Beograd

\title{
JAVNE SLUŽBE*
}

Treba.razlikovati organe državne i druge (javne) uprave od javnih službi. Javne službe vrše poslove od opšteg interesa za građane i organizacije, izvan su državne strukture i podležu nadzoru od strane ministarstava i drugih državnih organa. Zato, kada govorimo o javnim službama treba imati u vidu da se radi o javnom sektoru koji se deli na organe uprave koji vrše državnu vlast i javne ustanove i druge javne službe (javni saobraćaj, zdravstvene ustanove i dr.) koje vrše stručne i druge poslove za građane i organizacije i koje imaju javnu odgovornost za vršenje tih poslova. Kao zajednički naziv za sve te organe i organizacije upotrebljava se naziv Javne službe. Iako se organi državne uprave ne mogu poistovećivati sa javnim službama to se često čini, pa se i primenjivanje propisa o položaju zaposlenih i njihovim pravima, obavezama i odgovornostima koji se donose za organe državne uprave proširuje i na javne službe, što uvek nije ispravno, jer to dovodi do zavisnosti od budžetskog finansiranja javnih službi, smanjuje njihovu kreativnost i tržišnu orijentaciju u radu i jača birokratizam u društvu i nepotrebno administriranje.

Upravo takva pozicija javnih službi, uključujući pod taj pojam i organe državne uprave, u dobroj meri se propisuje u zakonima i drugim propisima, što dovodi do neracionalnosti i neefikasnosti, kako organa državne uprave tako i drugih javnih službi. Naime, organi državne uprave moraju ostati kao posebna kategorija koja je odgovorna za vršenje državne vlasti i za kontrolu pravilnog vršenja javnih službi u svim oblastima života, a ne da se ti organi poistovećuju sa javnim službama.

Stanje na saveznom nivou i na republičkom nivou u Republici Srbiji, prema važećim zakonima i drugim propisima i opštim aktima, jeste takvo da generiše samovolju i neodgovornost, kako u organima državne

* Rad primljen: 19. X 2001. 
uprave tako i u javnim službama koje vrše delatnosti za potrebe građana i organizacija (javni saobraćaj, zdravstvo, školstvo, socijalno osiguranje itd.).

Posle 5. oktobra 2000. godine stanje se nije bitnije promenilo.

Nisu doneti novi zakoni u oblasti državne uprave i javnih službi. Prethodni, još uvek važeći zakoni i drugi propisi i opšti akti, opterećeni su naglašenim monokratskim i hijerarhijskim odnosima, tako da vrlo malo prostora ima za samostalan i kreativan rad zaposlenih u državnim organima i javnim službama. S druge strane, zakoni su opterećeni normama koje daju diskreciona ovlašćenja funkcionerima koji rukovode organima državne uprave i javnim službama, kao i ovlašćenjima za odlučivanje i raspolaganje sredstvima namenjenim za rad organa i službi bez dovoljno kontrole i odgovornosti. Takvi zakoni i drugi propisi i opšti akti sporo se menjaju i nema dovoljno volje da se oni promene po uzoru na zakonodavstva drugih razvijenih evropskih zemalja i Evropske unije. Još uvek preovlađuje verbalizam kad je u pitanju promena zakonodavstva u oblasti državne uprave i javnih službi. Istina, u Republici Srbiji su preduzete mere na pripremi novih zakona o Vladi i o državnoj upravi, ali su nacrti tih zakona tek početkom septembra meseca 2001. godine dostavljeni odgovarajućim komisijama Vlade od strane ekspertskih grupa koje su ih pripremale.

Demokratičnost i zakonitost postupanja u organima državne uprave i javnim službama zavise pretežno od individualnih sklonosti i kompetentnosti funkcionera koji rukovode tim organima, odnosno službama. Zaposleni nemaju pravo na potpisivanje mišljenja i akata koje pripremaju, izuzev u određenim slučajevima u vršenju inspekcijskog nadzora. Zakoni su autoritativni u odnosu na zaposlene i diskrecioni u odnosu na rukovodioce. Takvi su ne samo materijalni nego i organizacioni propisi u oblasti uprave kao i opšti Zakon o opštem upravnom postupku i zakoni o posebnim upravnim postupcima.

Neophodno je izvršiti konsolidaciju materijalnih, organizacionih i procesnih zakona u oblasti državne uprave i javnih službi i ugraditi objektivne elemente umesto subjektivnih elemenata i obezbediti samostalnost i odgovornost zaposlenih u tim organima i službama u njihovom radu, bez unutrašnjih i spoljašnjih uticaja i pritisaka od strane funkcionera i organa, odnosno organizacija kao i pojedinih građana i grupa.

\section{A. SAVEZNI ORGANI I JAVNE SLUŽBE}

Posle donošenja Ustava SRJ od 27. aprila 1992. godine u saveznim organima nastavljen je da se primenjuje raniji Zakon o osnovama sistema državne uprave i o Saveznom izvršnom veću i saveznim organima uprave koji je donet u SFRJ 1978. godine (,Službeni list SFRJ”, br. 23/78) kojim su na etatistički i autistički način regulisani funkcionisanje i prava, 
dužnosti i odgovornosti organa državne uprave i drugih saveznih organa i organizacija (javnih službi).

Odredbe ovog zakona se primenjuju i danas u onim pitanjima koja se odnose na savezne organe uprave i savezne organizacije, odnosno savezne javne službe, koje kasnijim zakonima koji su doneti za pojedine savezne organe uprave (SMIP, SMUP) i podzakonskim propisima Savezne vlade nisu drukčije uređena. Ovaj zakon je posle njegovog donošenja 1978. godine menjan i dopunjavan trinaest puta (,Službeni list SFRJ”, br. 58/79, 21/82, 18/85, 37/88, 18/89, 40/89, 72/89, 42/90, 44/90, 74/90, 35/91. i „Službeni list SRJ”, br. 31/93. i 50/93). Prema tome, ovaj autoritativni i etatistički zakon primenjuje se i dalje u najvećem delu i u najvećem broju saveznih organa uprave i saveznih organizacija, naročito kad su u pitanju ovlašćenja funkcionera da donosi opšte akte i pojedinačna ovlašćenja prema zaposlenima, kao i privilegije funkcionera u odnosu na zaposlene u saveznim organima.

Uredbama Savezne vlade o obrazovanju saveznih ministarstava, drugih saveznih organa i organizacija i službi Savezne vlade (poslednja objavljena u „Službenom listu SRJ”, br. 24/2001. od 27. jula 2001. godine), uređena su i neka pitanja koja se po Ustavu SRJ mogu uredivati jedino zakonom i koja su uređena navedenim Zakonom iz 1978. godine. To su vrste i status funkcionera i njihov odnos prema zaposlenima. Te odredbe, kao i odredbe iz Zakona iz 1978. godine, zasnivaju se na štapsko-linijskoj organizaciji i ovlašćenjima funkcionera prema zaposlenima, koji prema zaposlenima imaju naredbodavna ovlašćenja.

Pored toga, nije učinjena razlika između takozvanih službenika koji vrše poslove službe i drugih zaposlenih koji vrše administrativno-tehničke, uslužne, stručne i druge poslove za organe uprave i za potrebe službenika u tim organima, tako da se svi smatraju službenicima (kuvari, vozači, ložači, konobari, električari, moleri, stolari, bravari, telefonisti, komercijalisti i dr.).

Nije učinjena podela na tzv. službenike koji obavljaju poslove iz osnovne delatnosti organa i službi i na nameštenike, koji obavljaju gore navedene praktično-zanatske i pomoćne poslove (kako je to, na primer, učinjeno u Zakonu SR Nemačke i drugih razvijenih zemalja).

Savezni zakoni i drugi savezni propisi ne omogućavaju ministrima i drugim funkcionerima (sekretarima ministarstava, pomoćnicima u ministarstvima i drugim saveznim organima, savetnicima i dr.) da uvažavaju nezavisnost i profesionalizam svojih potčinjenih viših državnih službenika.

Po važećim saveznim propisima nije moguća sistemska politika borbe protiv birokratije, otvaranje administracije prema javnosti i povećanje njene efikasnosti, dok se ne donesu odgovarajući savezni zakoni, i to: Zakon o saveznoj vladi, Zakon o saveznim organima uprave i saveznim organizacijama i Zakon o položaju zaposlenih u saveznim organima, čije donošenje je predviđeno u odredbama člana 77. tačka 10. Ustava SRJ. 
Zadržan je sistemski pravni osnov po kome birokratiju u saveznim organima možemo i dalje definisati po sovjetskom iskustvu kao ,...birokratizam koji znači formalno, bezdušno rasuđivanje, tumačenje i primenu pravnih normi, kanonizaciju misli i dela državnih službenika, odsustvo stvaralaštva i konkretnog prilaza ljudima i pojavama, neuvažavanje i nepoverenje prema zaposlenima i prema inicijativi koja dolazi odozdo..." (Вендров Е. Е., Правоведение, Москва 1969, str. 237).

Anahronizam je da takvi odnosi u saveznim organima uprave nisu menjani od 1978. godine iako je to bila obaveza po Ustavnom zakonu za sprovođenje Ustava SRJ iz 1992. godine.

Ne postoji kultura i praksa da se službeno publikuju priručnici kojima se objašnjavaju obaveze organa uprave i javnih službenika i (javnih službi) prema građanima i prava koja građani imaju po zakonu i drugim propisima, te kako najlakše i najjednostavnije mogu da dođu do tih organa, službenika i da ostvare svoja prava. Prema toj vrsti pomoći građanima i poboljšanju njihovog položaja, nema dovoljno sluha niti je to do sada često praktikovana pojava. U ovom pogledu pažnju zaslužuju izdanja komentara zakona i zbirki propisa i opštih akata koje pripremaju pojedini autori i izdavači radi komercijalne dobiti.

Pojedine naučne organizacije, agencije i novinske i TV kuće vrše povremene ankete uz pomoć donatora i sredstvima iz državnog budžeta u kojima se saopštavaju mišljenja korisnika usluga javnih službi. Međutim, stalna, sistematska i periodična istraživanja koje bi državni organi i javne službe neposredno organizovali nisu zastupljena.

Javni službenici pripremaju analize, informacije, platforme za vođenje politike, zakone i druge propise, planove i programe rada i rešavaju u upravnim stvarima i vrše upravni nadzor. U vršenju tih poslova javni službenici neposredno ne odlučuju. Oni te akte pripremaju za neposredne funkcionere koji rukovode organima uprave i javnim službama, odnosno za vladu i skupštinu. U upravnim stvarima u kojima na osnovu posebnog ovlašćenja funkcionera samostalno odlučuju, javni službenici dužni su na osnovu odredaba Zakona o opštem upravnom postupku („Službeni list SRJ", br. 33/97) da daju obrazloženja za svoje odluke u složenijim stvarima, a u jednostavnijim kada stranka to zahteva.

Savezni ministar, odnosno funkcioner koji rukovodi drugim saveznim organom ili organizacijom, odnosno službom, prema citiranim propisima, ovlašćen je da donosi (uz saglasnost Savezne vlade) opšti akt o organizaciji $i$ o sistematizaciji radnih mesta u organu, odnosno organizaciji ili službi. On u tom opštem aktu određuje organizacione jedinice i način njihovog operativnog rada kao i broj i vrste zaposlenih. On se meša u operativni rad odeljenja onoliko koliko se oseća kompetentnim a pravo na mešanje u rad odeljenja i neposrednih izvršilaca im je propisima dato.

Zakonom, Uredbom o obrazovanju organa, organizacija i službi i Uredbom i uputstvom o kancelarijskom poslovanju, kao i propisima o informisanju, pravo na davanje podataka i informacija medijima $\mathrm{i}$ javnosti isključivo je pravo funkcionera koji rukovodi organom, organizacijom, 
odnosno službom, a drugi funkcioneri i zaposleni te podatke i informacije mogu davati samo po izričitom odobrenju funkcionera i u granicama datog ovlašćenja.

Izričita zabrana davanja informacija stranci i javnom službeniku koji radi na njegovom slučaju nije propisana. Međutim, postoje instrukcije funkcionera u nekim slučajevima da se strankama ne daju podaci o licima koja rade u organu na određenom predmetu, da bi se organ i službenik zaštitio od pritiska stranke. U principu, stranka može da dođe do službenika koji radi na njenom predmetu i da se od njega obavesti o vremenu rešavanja njenog predmeta.

Po zakonu funkcioneri snose odgovornost za svoj rad, za rad organa, odnosno organizacije ili službe kojom rukovode i za rad zaposlenog u organu, organiziciji odnosno službi. Dakle, odgovornost je funkcionera i za korupciju i za loš rad potčinjenih. Međutim, funkcioner je odgovoran organu koji ga bira, imenuje, odnosno postavlja. Kako ne postoji Zakon o ministarskoj odgovornosti, ta odgovornost najčešće izostaje, a u slučaju teških kršenja prava i obaveza u vršenju funkcije funkcioner snosi politič$\mathrm{ku}$, materijalnu i krivičnu odgovornost. Politička odgovornost svodi se na smenjivanje sa funkcije ili podnošenje ostavke funkcionera. Politička odgovornost ne isključuje materijalnu i krivičnu odgovornost. Te odredbe sadržane su u Zakonu iz 1978. godine.

Ne postoji mehanizam zaštite službenika koji svog pretpostavljenog ili druge prijave za korupciju ili druge zloupotrebe. Nije propisan mehanizam koji bi ih štitio od „osvete”. Na primer, u takvom slučaju se službeniku u opštem aktu o organizaciji i sistematizaciji radnih mesta, za čije donošenje je nadležan funkcioner, može ukinuti radno mesto i službeniku uručiti otkaz, ukoliko se na njega ne primene direktne mere odmazde (udaljenje sa rada uz pokretanje postupka disciplinske odgovornosti i dr.).

Zakonom i drugim propisima nije utvrđena obaveza vođenja službenih evidencija (registara) o primanju i davanju poklona i drugih usluga funkcionerima i javnim službenicima koji obavljaju određene poslove koji imaju elemente koristoljublja (izvozno-uvozne dozvole, i dr.). Bilo je inicijativa da se donese zakon o davanju i primanju poklona i predloga da se prijavljuju pokloni, ali taj zakon nije donet. Isto tako, ne postoje propisi o prijavljivanju i popisivanju imovine na dan stupanja na funkciju i odlaska sa funkcije.

Ne postoji redovna rotacija (smena) službenika i postavljenih funkcionera na određenim poslovima, odnosno radnim mestima. Takva obaveza nije propisana. Jedino u slučaju utvrđenih nepravilnosti i disciplinskih ili drugih prekršaja službenika, propisuje se njegovo smenjivanje sa radnog mesta kao disciplinska mera (službenici koji vrše inspekcijski nadzor i dr.), ali se ta mera retko u praksi primenjuje, jer nema kontinuiranog praćenja rada tih službenika (nedostaju mehanizmi praćenja rada).

Ne vode se kampanje za upoznavanje javnosti sa procedurama izdavanja dozvola, odobrenja i dr., jer se smatra da su građani dužni da poznaju pravo (ignorantio iuris nocet). Međutim, za naplatu javnih prihoda 
vode se kampanje (ako od građana treba ubrati poreze i druge javne prihode).

Propisana je Ustavom i zakonom politička nezavisnost javnih službi (,...profesionalni pripadnici vojske i policije SRJ ne mogu biti članovi političkih stranaka" - član 42. stav 4. Ustava SRJ). ,Zaposleni u državnim organima, profesionalni pripadnici VOJSKE I POLICIJE NEMAJU pravo na štrajk" (član 57. stav 3. Ustava SRJ).

Nisu propisani mehanizmi za sprečavanje pritisaka na javne službenike ministara i drugih političara - Zakonom iz 1978. godine propisano je jedino da je službenik dužan da odbije nalog funkcionera koji predstavlja krivično delo, ali ako mu funkcioner ponovi nalog u pismenom obliku dužan je da ga izvrši.

Krivičnim zakonom propisane su kazne za primanje i davanje mita. Međutim, zakonima u oblastima uprave propisana je disciplinska odgovornost za primanje mita (Zakon o carinskoj službi i dr.). Disciplinska odgovornost za primanje i davanje mita ne isključuje krivičnu odgovornost ako to predstavlja i krivično delo.

Zapošljavanje i napredovanje u službi ne zavise u potpunosti od stručnosti. Raširena je praksa prijema u službu bez konkursa (posle obavljenog pripravničkog staža, preko zasnivanja radnog odnosa na određeno vreme, preuzimanjem i sl.). Funkcioneri se postavljaju bez konkursa iako je Zakonom iz 1978. godine (član 321) i kasnijim izmenama i dopunama tog zakona iz 1989. godine propisano da se radni odnos radnika u saveznim organima uprave i funkcionera zasniva na osnovu javnog konkursa, u skladu sa opštim aktom o sistematizaciji zadataka i poslova. Te odredbe Zakona nisu nikad u praksi primenjene kad je u pitanju zasnivanje radnog odnosa funkcionera u organima uprave i javnim službama. Oni su postavljani uvek bez konkursa od strane radnog tela (komisije) Savezne vlade. Nisu propisani visoki stručni kriterijumi za zasnivanje radnog odnosa visokih službenika i funkcionera ili se oni ne poštuju iako su propisani u pojedinim opštim aktima o organizaciji. Tzv. Merit-sistem pri zasnivanju radnog odnosa zaposlenih u organima uprave i javnim službama ne primenjuje se, a sva radna mesta nisu dostupna svima pod jednakim uslovi$m a$, tako da najsposobniji ne mogu da zauzmu najvažnija radna mesta. U tom pogledu savezni-propisi nisu usklađeni sa propisima razvijenih evropskih država i Evropske unije. Protiv uvođenja Merit-sistema u organe uprave i javne službe pri izboru kadrova postoje snažni otpori.

Ne postoje propisi koji sprečavaju nepotizam u državnim organima i javnim službama. Imamo mnogo slučajeva da u istom organu uprave rade članovi najuže porodice, da se zapošljavaju lica srodnici funkcionera i drugih zaposlenih itd.

$\mathrm{Ne}$ postoje pravila (propisi) kojima se uređuje primanje i davanje poklona i usluga javnim službenicima. Praksa davanja poklona i usluga je ukorenjena na mestima na kojima ima interesa da se takvi pokloni daju, odnosno primaju. 
Nisu uspostavljeni registri za evidentiranje poklona i usluga. Ne postoje službe koje vode takve registre. Pritužbe koje stranke upućuju i u kojima se žale na primanje poklona i usluga od strane nadležnog službenika rešavaju sami organi koji su nadležni za odnosne poslove, odnosno funkcioner koji rukovodi tim organom. U težim slučajevima može se pokrenuti disciplinski postupak ili podneti krivična prijava protiv odgovornog službenika. Medutim, takvi slučajevi su sasvim retki i nezapaženi.

Ne postoje bitna ograničenja zapošljavanja po prestanku rada u javnoj službi. Ograničenja se mogu predvideti pravilima službe u odnosu na nepodudarnost obavljanja poslova koji su imali karakter državne ili službene tajne. Međutim, ne postoje efikasna ograničenja da se poslovi obavljaju u svom preduzeću ili kod srodnika ili za njihov račun po prestanku rada u službi; čak, ni za vreme trajanja službe, što doprinosi štetnom delovanju u službi za račun privatnih delatnosti. Ta pitanja nisu dosledno normativno-pravno uredena kao ni sankcije.

Nisu propisani mehanizmi odlučivanja po pritužbama građana na rad javnih službenika (član 44. Ustava SRJ). Međutim, te pritužbe se razmatraju interno u organu, odnosno organizaciji ili službi u kojoj službenik radi i prema javnom službeniku može biti pokrenut odgovarajući postupak. Građani se obaveštavaju o rezultatu po njegovim pritužbama. Ne postoji jedinstveni organ koji rešava pritužbe građana na rad organa uprave i javnih službi i njihovih službenika. Ne postoji poseban sud ili organ koji bi rešavao takve pritužbe i preduzimao propisane mere. Ne postoji takav propis.

Posebnu pažnju zaslužuju Zakon o imovini SRJ i podzakonski propisi koje na osnovu njega donosi Savezna vlada i organi uprave i javne službe. Ti propisi su značajni izvori korupcije.

\section{B. STANJE U REPUBLICI SRBIJI}

U Republici Srbiji je donet Zakon o državnoj upravi (,Službeni glasnik RS", br. 20/92, 48/93, 53/93 i 48/94).

Prema odredbama ovog zakona, organi državne uprave obavljaju poslove na osnovu i u okviru Ustava i zakona.

U okviru nadležnosti organa državne uprave, ovlašćeno lice primenjuje propise i na osnovu utvrđenih činjenica i drugih okolnosti, po svom uverenju ocenjuje dokaze, donosi akte i preduzima druge upravne mere i radnje.

Pojedinačni akti, mere i radnje organa državne uprave zasnivaju se na zakonu ili drugom propisu donetom na osnovu zakona.

Organi državne uprave dužni su da svakom obezbede jednaku pravnu zaštitu i ostvarivanje njegovih prava, obaveza i interesa.

Rad organa državne uprave dostupan je javnosti. 
Javnost u radu organa državne uprave može se ograničiti ili isključiti u slučajevima utvrđenim zakonom. Ovim je relativizirana javnost rada organa državne uprave.

Rad organa državne uprave podložan je kritici građana, kao i javnoj kontroli građana na način utvrđen zakonom.

Zaposleni u državnim organima i postavljena lica dužni su da obavljaju svoje poslove savesno i nepristrasno, pri čemu se ne mogu rukovoditi svojim političkim ubeđenjima, niti ih mogu izražavati i zastupati.

Zabranjeno je u organima državne uprave osnivati političke stranke i druge političke organizacije ili pojedine njihove unutrašnje oblike.

Sredstva za finansiranje poslova državne uprave obezbeđuju se u budžetu.

Ministri ne mogu vršiti nikakvu javnu, profesionalnu i drugu dužnost, koja je nespojiva sa njegovom funkcijom ministra, kao ni drugi funkcioneri koje postavlja Vlada, izuzev kad im to odobri (uz saglasnost) Vlada.

Organi državne uprave, preduzeća i druge organizacije dužni su da građanima omoguće nesmetano ostvarivanje njihovih prava i obaveza, daju im potrebne podatke i obaveštenja, pružaju pravnu pomoć, sarađuju sa građanima, poštuju ljudsku ličnost i čuvaju ugled organa državne uprave.

Organi državne uprave dužni su da razmatraju predstavke, peticije i predloge koje im građani podnose, da postupaju po njima i o tome obaveštavaju građane.

Položaj funkcionera koji rukovode organima državne uprave (ministara i drugih funkcionera) određen je na analogan način kao u saveznim organima uprave. Tako, na primer, članom 39. Zakona o državnoj upravi Republike Srbije propisano je da ,se unutrašnja organizacija i sistematizacija radnih mesta u organu državne uprave uređuje aktom koji donosi ministar, odnosno funkcioner koji rukovodi posebnom organizacijom, uz saglasnost Vlade".

Državna uprava u Republici Srbiji zasniva se na principu centralizacije i dekoncentracije vršenja poslova (preko područnih organizacionih jedinica), dok se unutrašnja organizacija i rukovođenje zasnivaju na linijsko-hijerarhijsko-štapskom organizovanju.

Lokalna samouprava uređena je Zakonom o lokalnoj samoupravi („Službeni glasnik RS”, br. 49/99. i 27/2001). Lokalna samouprava ostvaruje se u opštinama, gradovima i okruzima kao i u autonomnim pokrajinama. Organi lokalne samouprave nemaju upravna ovlašćenja, izuzev u slučajevima kad su im pojedina takva ovlašćenja poverena zakonom.

Rad Javnih službi u Republici Srbiji uređen je analogno radu organa uprave, Zakonom o javnim službama Republike Srbije (,Službeni glasnik RS”, br. 42/91. i 71/94). Javnom službom u smislu ovog zakona smatraju se ustanove, preduzeća i druge organizacije, drugi oblici organizovanja, utvrđeni zakonom, koji obavljaju delatnosti odnosno poslove kojima se obezbeđuje ostvarivanje prava građana odnosno zadovoljavanje potreba 
građana i organizacija, kao i ostvarivanje drugog zakonom utvrdenog interesa u određenim oblastima.

Radi obezbeđivanja ostvarivanja prava utvrđenih zakonom i ostvarivanja drugog zakonom utvrđenog interesa u oblasti obrazovanja, nauke, kulture, fizičke kulture, učeničkog i studentskog standarda, zdravstvene zaštite, socijalne zaštite, društvene brige o deci, socijalnog osiguranja, zdravstvene zaštite životinja, osnivaju se ustanove.

Za obavljanje delatnosti odnosno poslova utvrđenih zakonom u oblasti javnog informisanja, PTT saobraćaja, energetike, puteva, komunalnih usluga i drugim oblastima utvrđenim zakonom, osnivaju se preduzeća.

Navedene ustanove, odnosno preduzeća, mogu osnivati republika, autonomna pokrajina, grad, opština i druga pravna i fizička lica.

Javnom ustanovom odnosno preduzećem upravlja upravni odbor, a rukovodi direktor. Status javnih ustanova i javnih preduzeća uređuje se osnivačkim aktom (zakonom, uredbom ili odlukom) i statutom, a način rada organa uređuje se poslovnikom.

Nadležni organi uprave vrše upravni i stručni nadzor nad radom javnih ustanova, odnosno javnih preduzeća.

Finansiranje javnih ustanova, odnosno javnih preduzeća vrši se iz budžeta naplaćivanjem usluga, prodajom proizvoda, donacijama i $\mathrm{dr}$.

Pojedinačni akti javnih službi (ustanova i preduzeća) imaju karakter upravnih akata i protiv njih dozvoljena je žalba, a takođe, protiv konačnih pojedinačnih akata javnih službi može se voditi upravni spor o zakonitosti tih akata.

Dakle, sfera organa državne uprave i javnih službi u Republici Srbiji je posebnim zakonima propisana, s tim što sfera državne uprave ima ekskluzivan položaj u pravnom sistemu. Na ovaj način se državnoj upravi ograničava pravo da se ona ponaša kao javna služba, odnosno preduzeće (menadžerski) i organi državne uprave se zadržavaju kao eminentno izvršni organi države, sa jasno propisanim obavezama i ovlašćenjima i odgovornostima. Ovo se posebno odnosi na ministarstva.

Zakonom o ministarstvima Republike Srbije (,Službeni glasnik RS”, br. 7/91, 8/91, 76/91, 20/92, 87/92, 67/93, 23/96, 5/97, 47/99, 38/2000. i 4/2001) propisano je da „Poslove državne uprave utvrđene zakonom i propisima donetim na osnovu zakona obavljaju ministarstva i organi uprave u sastavu ministarstava".

Prema članu 2. tog zakona, obavljanje određenih poslova državne uprave zakonom se može poveriti organima autonomnih pokrajina, gradova, opština, kao i preduzeća i drugih organizacija.

Prema članu 28. st. 1-4. Zakona, ministar predstavlja ministarstvo i rukovodi njegovim radom. Ministar obezbeđuje sve potrebne uslove za rad ministarstva i s tim u vezi donosi odgovarajuće odluke $i$ raspolaže sredstvima za njegov rad.

Za svoj rad i rad ministarstva kojim rukovodi, ministar odgovara Narodnoj skupštini i Vladi. 
Prema navedenim odredbama ministar monokratski odlučuje. Službenici u ministarstvu nemaju potrebnu samostalnost $i$ odgovornost $u$ radu.

Prema članu 94. Ustava Republike Srbije, poslove državne uprave obavljaju ministarstva: primenjuju zakone i druge propise i opšte akte Narodne skupštine i Vlade, kao i opšte akte predsednika Republike, rešavaju u upravnim stvarima, vrše upravni nadzor i obavljaju druge upravne poslove utvrđene zakonom.

Ministarstva su samostalna u vršenju Ustavom i zakonom određenih nadležnosti. Za vršenje određenih poslova državne uprave obrazuju se organi uprave u sastavu ministarstava, a za vršenje stručnih poslova obrazuju se posebne organizacije.

Zakonom se određuje organizacija i nadležnost ministarstava i organa uprave u njihovom sastavu i posebnih organizacija. Određena upravna ovlašćenja zakonom se mogu poveriti preduzećima i drugim organizacijama.

Zakonom o radnim odnosima u državnim organima Republike Srbije („Službeni glasnik RS”, br. 48/91. i 66/91) uređeni su prava, obaveze i odgovornosti iz radnih odnosa lica zaposlenih u ministarstvima, posebnim organizacijama, sudovima, javnim tužilaštvima, javnom pravobranilaštvu, organima za prekršaje $i$ u službama Narodne skupštine, predsednika Republike, Vlade $i$ Ustavnog suda koji se primaju u radni odnos odlukom funkcionera koji rukovode ovim organima $i$ službama, određena prava predsednika Republike i određena prava, obaveze i odgovornosti lica koja bira Narodna skupština i lica koja postavlja Vlada, odnosno drugi nadležni organ.

U ovom zakonu dati su određeni principi koji se odnose na zasnivanje radnog odnosa, rasporedivanje zaposlenih, obaveze u službi, zvanja i zanimanja, platne grupe, način utvrđivanja plata itd. Međutim, i u ovom zakonu nisu učinjeni bitni pomaci na utvrdivanju kriterijuma za izbor službenika po principima tzv. Merit-sistema. Konkretna pitanja položaja službenika i funkcionera u organima uprave i drugim državnim organima i javnim službama uređuju se podzakonskim propisima Narodne skupštine i Vlade. U tom pogledu i ovaj zakon je nepotpun i neophodno je da se izvrši potpuna rekonstrukcija zakonodavstva o upravi i javnim službama u Republici Srbiji. 